WSRC-TR-92-139-Rev. I

\title{
ANALYSIS OF DEPOSIT FROM K-REACTOR HEAT EXCHANGER (U)
}

by E.W. Baumann

Westinghouse Savannah River Company

Savannah River Site

Aiken, South Carolina 29808
WSRC-TR--92-139-Rev . 1

DE93 008797

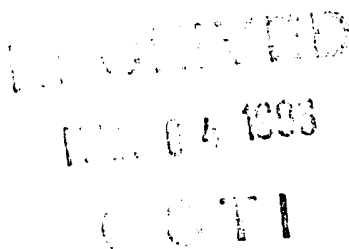

This paper was prepared in connection with work done under Contract No. DE-AC09-89SR18035 with the U.S. Department of Energy. By acceptance of this paper, the publisher and/or recipient acknowledges the U.S. Government's right to retain a nonexclusive, royalty-free license in and to any copyright covering this paper, along with the right to reproduce and to authorize others to reproduce all or part of the copyrighted paper. 


\section{DISCLAIMER}

This report was prepared as an account of work sponsored by an agency of the United States Government. Neither the United States Government nor any agency thereof, nor any of their employees, makes any warranty, express or implied, or assumes any legal liability or responsibility for the accuracy, completeness, or usefulness of any information, apparatus, product, or process disclosed, or represents that its use would not infringe privately owned rights. Reference herein to any specific commercial produch, process, or service by trade name, trademark, manufacturer, or otherwise does not necessarily constitute or imply its endorsement, recommendation, or favoring by the United States Government or any agency thereof. The views and opinions of authors expressed herein do not necessarily state or reflect those of the United States Government or any agency thereof.

This report has been reproduced directly from the best available copy.

Available to DOE and DOE contractors from the Office of Scientific and Technical Information, P.O. Box 62, Oak Ridge, TN 37831; prices available from (615) 576-8401, FTS 626-8401.

Available to the public from the National Technical Information Service, U.S. Department of Commerce, 5285 Port Royal Rd, Springfield, VA 22161. 


\section{WESTINGHOUSE SAVANNAH RIVER COMPANY INTER-OFFICE MEMORANDUM}

March 20, 1992

TO:

C.E. Coffey, 773-A

FROM:

E.W. Baumeng $773-41 \mathrm{~A}$
$(5-1421)$

Technical Reviewer g.P. Itoucll

ANALYSIS OF DEPOSIT FROM K-REACTOR HEAT EXCHANGER AA(U)

\section{INTRODUCTION}

Characterization of deposits from the reactor system provides a means of directly assessing corrosion and chemistry conditions within the system. The recent analysis of debris vacuumed from the bottom of $\mathrm{K}$-Reactor tank(1) provided information and reassurance about the conditions within the tank that would affect corrosion or moderator chemistry. Further opportunity for surveillance within the reactor system was recognized when solid deposits were found on the moderator side of the K-Reactor heat exchanger 4A that failed in December 1991. A sample of deposited material from the face of the tube sheet at the inlet end was removed under the direction of Equipment Engineering Section personnel.

The material was analyzed by the Analytical Development Section by techniques used earlier for the K-tank debris. Elemental content was determined by Scanning Electron Microscopy/Energy Dispersive Spectroscopy (SEM/EDS). Total chlorine content was determined by neutron activation analysis. Crystalline components were identified by $\mathrm{X}$-Ray diffraction, and radionuclidic content characterized by alpha pulse height analysis, beta counting, scintillation counting, and gamma spectroscopy. The purpose of this memorandum is to report the results of these analyses.

\section{SUMMARY}

The material was similar in composition to that seen in the K-Tank debris, wich no recognized impact on corrosion or moderator chemistry. The total chlorine content was below the limit of detection: less than 14 parts per million, indicating no source or sink of chlorides. The matrix material consisted of oxides of aluminum, silicon, and iron, which would be indigenous to the reactor system. Lesser elements identified were molybdenum, manganese, zirconium, chromium, 
potassium, and titanium. Some of these may have been introduced during the heat exchanger examination, but none are recognized as deleterious to the system. Crystalline components were hydrated aluminas (gibbsite, böhmite, and bayerite) and silica. The radionuclides were Co-60 from neutron activation of stainless steel, actinides from long-term irradiation of uranium, and long-lived fission products.

\section{DISCUSSION}

The material, sample ADS-2000071717, was rusty-looking and scale-like. Portions were taken for neutron activation determination of total chlorine, morphology and elemental analysis by SEM/EDS, determination of crystalline components by $\mathrm{X}$-Ray diffraction, and radioactive characterization.

\section{TOTAL CHLORINE CONTENT}

The total chlorine, determined by neutron activation, was less than 14 parts per million. This was the limit of detection, which is dependent on the size of the sample activated.

\section{MORPHOLOGY/ELEMENTAL ANALYSIS}

Images and identification of elemental content of the material were obtained by SEMIEDS. Aluminum and silicon, with some iron, were the matrix materials. Other elements identified were molybdenum, manganese, zirconium, chromium, potassium, and titanium. Some of these may have been introduced during the heat exchanger examination; for example the titanium is believed to have come from the titanium-tipped core drill used.

Images of typical material at magnifications of $8 x, 50 x, 150 x$ and $1000 x$ are given in Figures $1 \mathrm{a}$ and $1 \mathrm{~b}$. Additional images with spots where elemental composition was determined by EDS are given in Figures $2 \mathrm{a}$ and $2 \mathrm{~b}$. Table 1 provides a rough estimate of the relative abundance of each element from the EDS scans. The matrix (spots $I$ and $M$ ) was primarily aluminum and silicon, with some iron. Significant elements in other spots were titanium, (Spots $A$ and $K$ ), molybdenum (Spot B), manganese (Spot E), zirconium (Spot F), chromium (Spot H), potassium (Spot N).

\section{X-RAY DIFFRACTION}

$X$-ray diffraction showed the primary crystalline components were various hydrated aluminum oxides. The principal alumina was gibbsite, a trihydrate, which is the stable phase below $140^{\circ} \mathrm{C}$. Next in abundance was böhmite, a monohydrate known to be formed on fuel cladding surfaces. Also seen was bayerite, a trihydrate. Silica was also identified.

The X-Ray diffraction pattern showed the crystalline components, in order of decreasing predominance, as: Gibbsite $\left(\alpha-1_{2} \mathrm{O}_{3} .3 \mathrm{H}_{2} \mathrm{O}\right)$, Bohmite $\left(\alpha-\mathrm{l}_{2} \mathrm{O}_{3} . \mathrm{H}_{2} \mathrm{O}\right)$, Bayerite $\left(\beta-\mathrm{l}_{2} \mathrm{O}_{3} .3 \mathrm{H}_{2} \mathrm{O}\right)$, and Quartz $\left(\mathrm{SiO}_{2}\right)$. 
WSRC-TR-92-139. Rev. 1

Revised for External Release

\section{RADIOACTIVE CHARACTERIZATION}

The sample was treated in several ways to define the radioactivity, which consisted of long-lived radioisotopes: Co-60 from neutron activation of stainless steel, actinides from prolonged neutron irradiation of uranium, and fission products. Details are given below and in Tables 2 and 3.

\section{Leachable Activity}

The radioactivity leached from the sample by $8 \mathrm{M}$ nitric acid is characterized in Table 2. Americium-241 was identified by the $59.5 \mathrm{kev} \gamma$-ray. Ordinarily Am-241 is included with $\mathrm{Pu}-238$ from $\alpha$-spectrometry because the $\alpha$-energies are similar. In the K-Tank debris(1) Cobalt-60 dominated the gamma spectrum and Am-241 was not uniquely identified.

The beta spectrum of the leachate revealed two or three beta components. One component, which had an endpoint beta energy between 20 and $30 \mathrm{kev}$ could possibly be $\mathrm{Pu}-241$.

The gross alpha plus beta by liquid scintillation was significantly higher than the sum of gross alpha and gross beta by the plate method. This could be due to losses from plate preparation and counting, such as evaporation of volatile components or sample self-absorption of low energy beta particles.

\section{Gamma Scan}

A second portion of the sample was placed in a tube and counted on a gamma detector. The results of this gamma scan are given in Table 3 . Co-60 is a neutron activation product of the Co-59 in stainless steel. The other radionuclides, with the exception of Am-241, are fission products.

\section{REFERENCES}

1. E.W.Baumann, Analysis of Debris Vacuumed from K-Reactor Tank, WSRCTR-92-027 (January 20, 1992). 
WSRC-TR-92-139. Rev. 1

Revised for External Release

Table 1

ELEMENTAL CONTENT BY SEM/EDS

$\begin{array}{lllll}\text { Spot } & \text { Major } & \text { Minor } & \text { Trace } & \text { Also Detected } \\ \mathrm{A} & \mathrm{Ti} & & \mathrm{Al}, \mathrm{Si} & \mathrm{Fe} \\ \mathrm{B} & \mathrm{Mo} & \mathrm{Al}, \mathrm{Si} & \mathrm{Fe} & \mathrm{Ti}, \mathrm{Mn} \\ \mathrm{C} & \mathrm{Fe} & \mathrm{Al}, \mathrm{Si} & & \mathrm{Ti}, \mathrm{Mo}, \mathrm{Mn} \\ \mathrm{D} & \mathrm{Al}, \mathrm{Si}, \mathrm{Fe} & & \mathrm{Mn}, \mathrm{K} & \mathrm{Ti}, \mathrm{Ca} \\ \mathrm{E} & \mathrm{Mn} & \mathrm{Al}, \mathrm{Si}, & \mathrm{Ti}, \mathrm{K}, \mathrm{Ca} & \\ \mathrm{F} & \mathrm{Si}, \mathrm{Zr} & & \mathrm{Si} & \mathrm{Al} \\ \mathrm{G} & \mathrm{Fe} & & \mathrm{Ni} & \mathrm{Al} \\ \mathrm{H} & \mathrm{Fe} & \mathrm{Si}, \mathrm{Cr} & \mathrm{Fi} & \mathrm{Ti}, \mathrm{Mn}, \mathrm{K}, \mathrm{Ca} \\ \mathrm{I}(\mathrm{Matrix}) & \mathrm{Al}, \mathrm{Si} & \mathrm{Al}, \mathrm{Si} & \mathrm{Ca} & \mathrm{Ti}, \mathrm{Fe}, \mathrm{Mo}, \mathrm{K} \\ J & \mathrm{Mn} & \mathrm{Al}, \mathrm{Si} & \mathrm{Fe} & \\ \mathrm{K} & \mathrm{Ti} & \mathrm{Si} & \mathrm{Al} & \\ \mathrm{L} & \mathrm{Fe} & \mathrm{Al} & \mathrm{Fe} & \mathrm{Ti}, \mathrm{Mn}, \mathrm{K}, \mathrm{Ca} \\ \mathrm{M} \text { (Matrix) } & \mathrm{Si} & \mathrm{K} & \mathrm{Fe} & \mathrm{Ti}, \mathrm{Mn}\end{array}$

Table 2

LEACHABLE ACTIVITY

Technique Gross Activity

Gross Alpha( $\alpha)$
Isotope

$41871 \mathrm{dpm} / \mathrm{g}$

$102367 \mathrm{dpm} / \mathrm{g}$

8.64 E6 dpm/g

Gross Beta( $\beta)$

Amount

$\mathrm{Pu}-238$

Am-241

$\mathrm{Pu}-239$

$\mathrm{Cm}-244$
$30.8 \%$

$39.7 \%$

$18.1 \%$

$10.1 \%$

\section{Liquid Scintillation}

$$
\text { Gross }(\alpha+\beta) *
$$

Gamma Scan

\section{Co -60}

Am-241
$1.8 \mathrm{E}-2 \mu \mathrm{Ci} / \mathrm{g}$

$7.48 \mathrm{E}-3 \mu \mathrm{Ci} / \mathrm{g}$

*Much greater than sum of gross alpha and gross beta; see text. 
WSRC-TR-92-139. Rev. 1

Revised for External Release

Table 3

GAMMA SCAN

Isotope Amount, $\mu \mathrm{Ci} / \mathrm{g}$

Co-60

$7.95 \mathrm{E}-1$

Ru-106

$8.29 \mathrm{E}-2$

$\mathrm{Sb}-125$

Cs-137

2.j3 E-2

Ce-144

$2.86 \mathrm{E}-3$

Eu-154

$8.59 \mathrm{E}-3$

Am-241

$5.13 \mathrm{E}-3$

$9.22 \mathrm{E}-1$ 
WSRC-TR-92-139. Rev. 1

Revised for External Release

FIGURE 1a

\section{TYPICAL MATERIAL AT $8 x$ and 75x MAGNIFICATIONS}
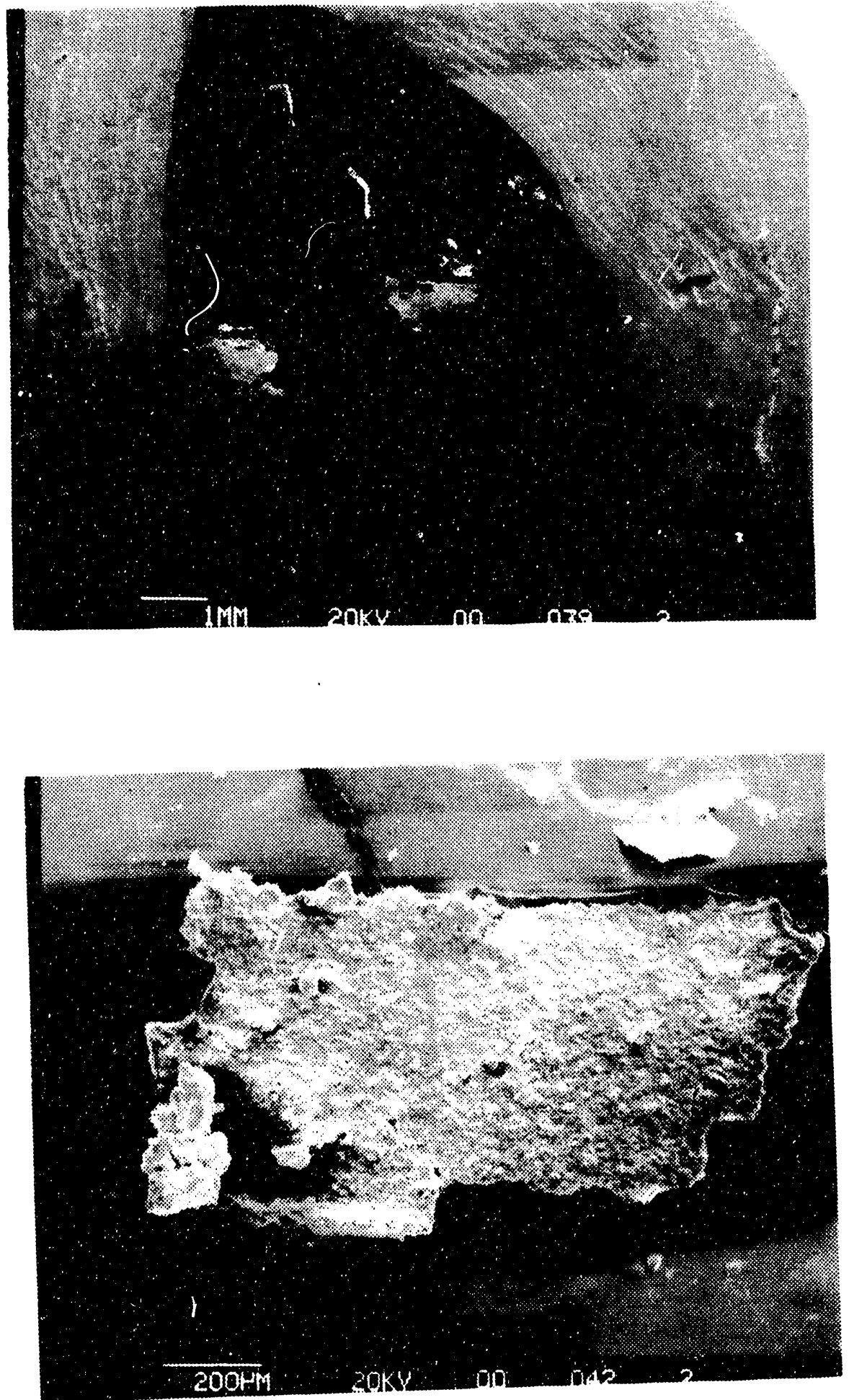

Page 6 of 9 
WSRC-TR-92-139. Rev. 1

Revised for External Release

FIGURE 1b

TYPICAL MATERIAL AT 150x and 1000x MAGNIFICATIONS
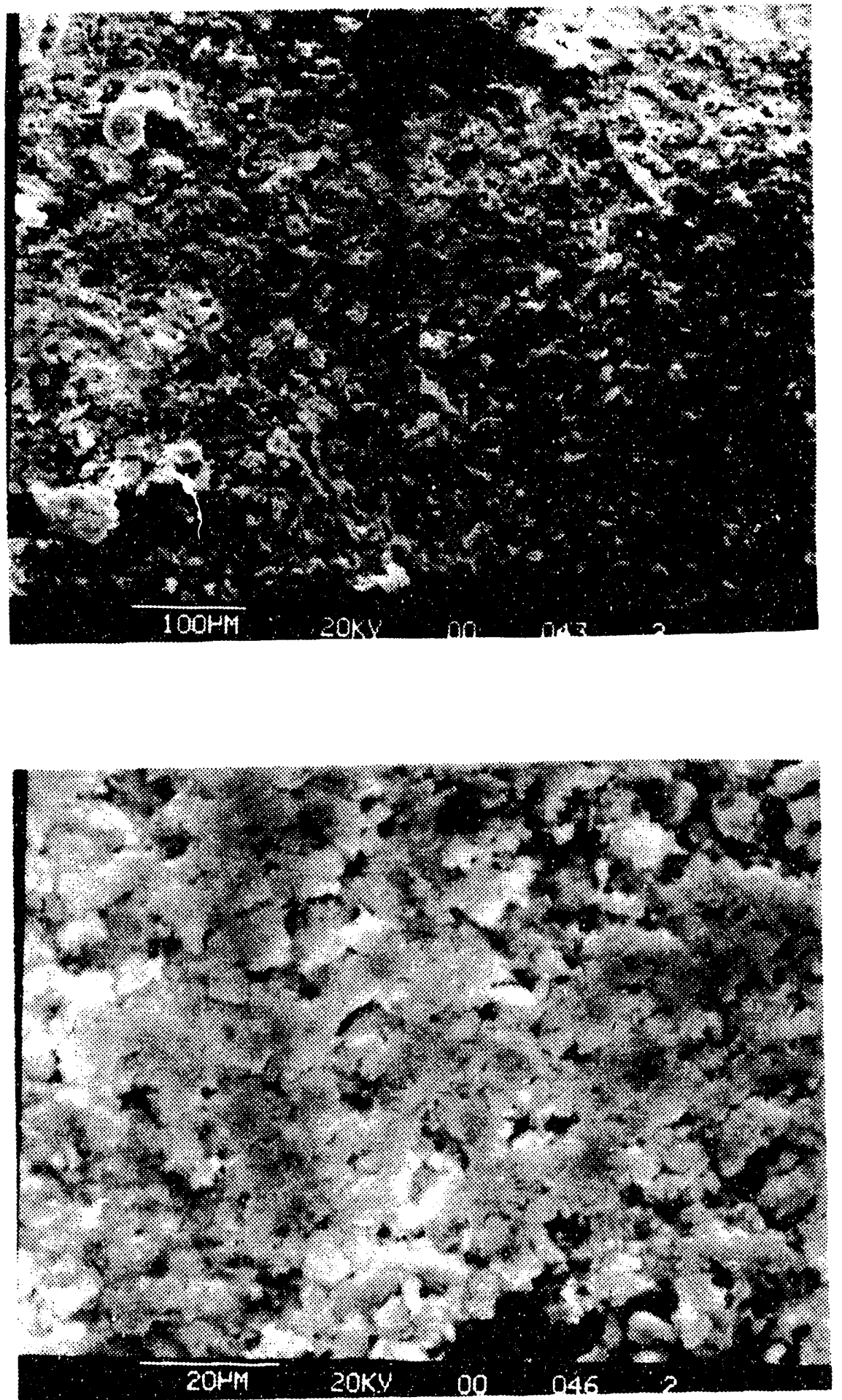

Page 7 of 9 
WSRC-TR-92-139. Rev. 1

FIGURE 2a

SEM/EDS IMAGES OF MATERIAL: SPOTS A TO I (Lettered spots identified in Table 1)
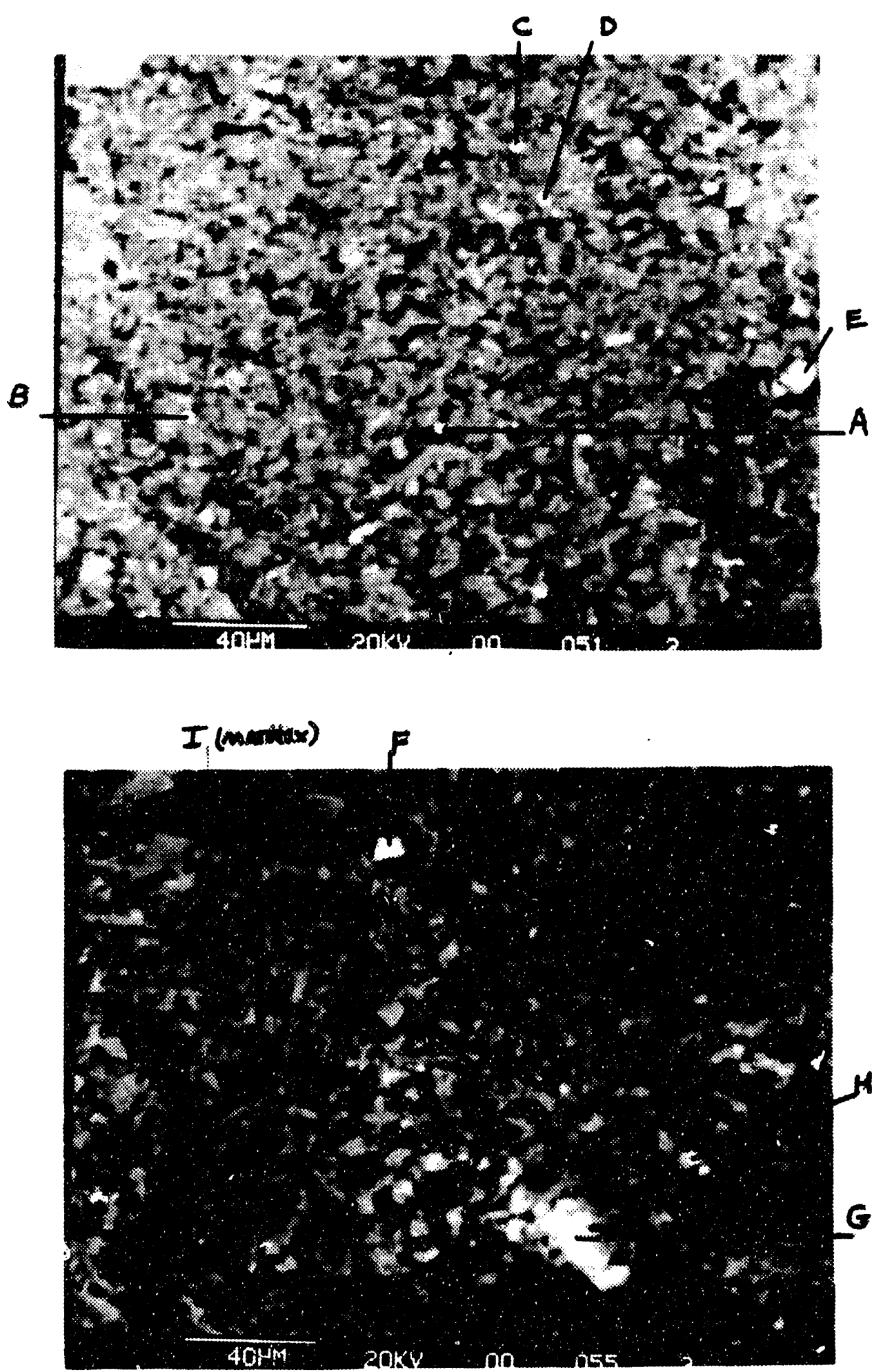

Page 8 of 9 
WSRC-TR-92-139. Rev. 1

Revised for External Release

\section{FIGURE 2b}

SEM/EDS IMAGES OF MATERIAL: SPOTS $J$ TO $M$ (Lettered spots identified in Table 1)
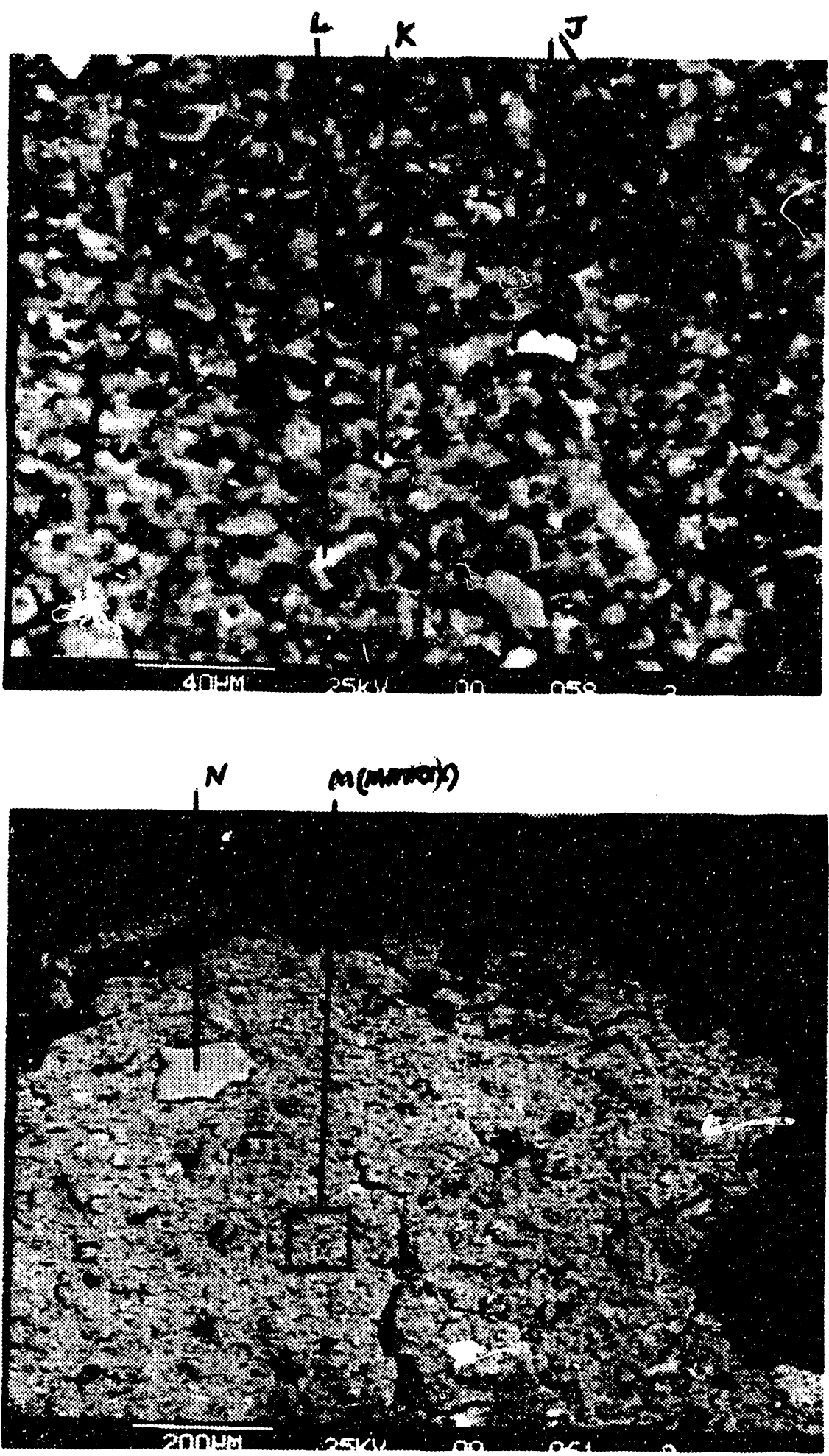

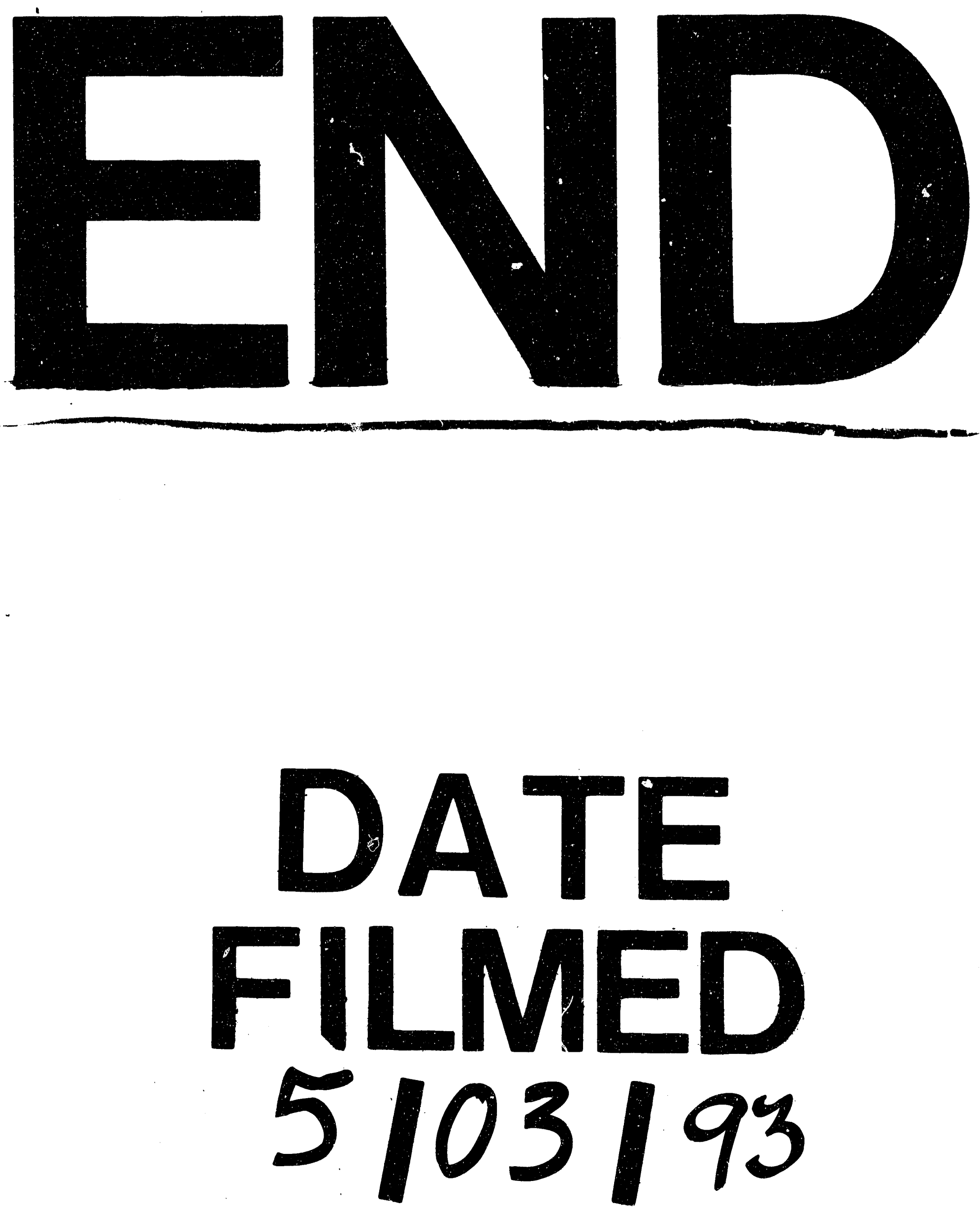